\title{
The possible use of scarce soluble materials as a source of phosphorus in Vicia faba L. grown in calcareous soils
}

\author{
Abdelmonem Mohamed ELGALA ${ }^{1}$ and Shaimaa Hassan ABD-ELRAHMAN ${ }^{1,2}$
}

Received September 13, 2020; accepted August 06, 2021. Delo je prispelo 13. septembra 2020, sprejeto 6. avgusta 2021

The possible use of scarce soluble materials as a source of phosphorus in Vicia faba L. grown in calcareous soils

Abstract: Phosphorus (P) is affected by many factors that minimize its solubility especially in calcareous soils. The aim of this work was to conduct laboratory and greenhouse experiments to study the effect of using $\mathrm{P}$ solubilizing substances, i.e., compost, humic acid (HA), citric acid and ethylene di-amine tetra acetic acid (EDTA), and rhizobacteria, Bacillus megaterium var. phosphaticum on solubilizing P from different sources, ordinary superphosphate (OSP), rock phosphate (RP) and basic slag (BS). The effect of these treatments on the P-availability in El-Nubaria calcareous soil and P- uptake by faba bean (Vicia faba 'Giza 843') were studied. Obtained results showed that the solubility of $\mathrm{P}$ sources differs in their ability to release soluble $\mathrm{P}$ in the following order: OSP $>\mathrm{RP}>\mathrm{BS}$. The following descending order was appeared of available $\mathrm{P}$ in soil with addition of solubilizing agents: citric acid $>$ EDTA $>$ HA $>$ compost for these sources of P, for both experiments. Regarding the interaction between solubilizing agents, the treatments of HA combined with EDTA or citric acid were superior in giving high concentrations in soil, and vigor plant growth. In addition, the solubility of $\mathrm{P}$ increased by about 5-6 times for all sources in the presence of P- dissolving bacteria. It seemed that the presence of appreciable amounts of $\mathrm{Mg}, \mathrm{S}, \mathrm{Fe}, \mathrm{Mn}, \mathrm{B}$ and other elements in BS played a role in enhancing plant growth and increasing yield, especially in the presence of added bacteria. BS could be used in calcareous soils and for soils characterized by low nutrient supply as sandy.

Key words: phosphorus sources; basic slag; organic substances; chelating substances; P availability; P dissolving bacteria; calcareous soils; Vicia faba
Možnost rabe slabo topnih snovi kot vir fosforja pri gojenju boba (Vicia faba L.) na apnenčastih tleh

Izvleček: Na topnost fosforja (P) vplivajo številni dejavniki, še posebej v apnenčastih tleh. Namen te raziskave je bil izvesti poskus v laboratoriju in rastlinjaku za preučevanje učinkov fosfor sproščajočih snovi kot so kompost, huminska kislina (HA), citronska kislina, etilen diamin tetra ocetna kislina (EDTA) in rizobakterij (Bacillus megaterium var. phosphaticum) na topnost fosforja iz različnih virov kot so navaden superfosfat (OSP), fosfat $\mathrm{v}$ kamnini (RP) in tomaževa žlindra (BS). Preučevani so bili učinki teh obravnavanj na dostopnost fosforja $\mathrm{v}$ apnenčastih tleh v El-Nubaria, Egipt in privzem fosforja v bob (Vicia faba 'Giza 843'). Rezultati so pokazali, da se topnost fosforja iz različnih virov razlikuje glede na njegovo sposobnost sproščanja $\mathrm{v}$ naslednjem vrstnem redu: OSP > RP > BS. Po dodatku agensov za topnost se je $\mathrm{V}$ tleh pojavil naslednji padajoči redosled razpoložljivega $\mathrm{P}$ : citronska kislina $>$ EDTA $>$ HA $>$ kompost, za vse vire fosforja $\mathrm{v}$ obeh poskusih. Glede na interakcije med agensi za topljenje se je obravnavanje HA v kombinaciji z EDTA ali citronsko kislino izkazalo kot najboljše, $z$ največjo koncentracijo topnega $\mathrm{P} v$ tleh in najboljšo rastjo rastlin. Dodatno se je vsebnost $\mathrm{P}$ povečala za okrog 5-6 krat pri vseh virih $\mathrm{P} v$ prisotnosti fosfor sproščajočih bakterij. Zdi se, da je je prisotnost precejšnih količin Mg, S, Fe, Mn, B in drugih elementov v tomaževi žlindri vplivala na pospešeno rast rastlin in povečanje pridelka, še posebej ob dodatku bakterij. Tomaževa žlindra bi se torej lahko uporabljala na apnečastih tleh in v peščenih tleh, ki jih označuje majhna vsebnost hranil.

Ključne besede: viri fosforja; tomaževa žlindra; organske snovi; helatirajoče snovi, razpoložljivost $\mathrm{P}$; P raztapljajoče bakterije; apnenčasta tla; Vicia faba

1 Soil Science Department, Faculty of Agriculture 11241, Ain Shams University, Egypt

2 Corresponding author, e-mail: Shaimaa_Hassan@agr.asu.edu.eg 


\section{INTRODUCTION}

In Egypt, phosphorus $(\mathrm{P})$ is the second major fertilizer comes after nitrogen and it is added to the soil mainly as an ordinary superphosphate (OSP). Phosphorus is an insoluble element in alkaline soil especially in soils containing high calcium carbonate, e.g., calcareous soils, which causes rapid precipitation to insoluble phosphate forms (Elgala \& Amberger, 2017). The definition of calcareous soils, as reported by Hopkins \& Ellsworth (2005), that are having significant quantities of calcium or magnesium carbonate (2-12\% depending on their particle size). These salts dissolve in neutral to acid soil $\mathrm{pH}$ (7-6.5), but not readily dissolve in alkaline soil (at about $\mathrm{pH} \geq 8$ ) and, instead, serves as a sink for surface adsorbed calcium phosphate precipitation. In other words, calcareous soils with high $\mathrm{pH}$ resulting from high content of salts or $\mathrm{Na}^{+}$and $\mathrm{OH}^{-}$ions, made $\mathrm{P}$ is a limiting factor, causing nutritional stress conditions.

Many factors affect the solubility of $\mathrm{P}$ in soil and its availability to growing plants, particularly under P-stressed conditions: with using rock phosphate or other untraditional components as a source of $\mathrm{P}$; such as acidifying the root medium (Houassine, 2020) and adding organic acids, amino acids and other chelating substances (Grover, 2003; Taskin et al., 2019; Elhag et al., 2019). Accordingly, getting benefit of factors that help in increasing solubility and availability of $\mathrm{P}$ from insoluble sources may encourage the use of rock phosphate (RP) or recycling untraditional sources i.e., basic slag (BS), even under alkaline conditions, with preserving the environment from contamination. Basic slag or steel slag, as common, contains calcium oxide $(\mathrm{CaO}, 40-$ $50 \%)$ and silica $\left(\mathrm{SiO}_{2}, 10-28 \%\right)$. Also, it includes alumina $\left(\mathrm{Al}_{2} \mathrm{O}_{3}, 1-3.5 \%\right)$ and magnesium oxide (MgO, 2.5-10 $\%$ ), as well as iron oxide (FeO, 14-22 \%) and manganese oxide (MnO, 1.5-6\%), total Fe (17-27 \%), and appreciable amounts of $\mathrm{P}, \mathrm{K}, \mathrm{S}$, and micronutrients (Tsakiridis et al., 2008; Yildirim \& Prezzi, 2011; Bing et al., 2019). BS could be used in agricultural fertilizers, and environmental protection (Bing et al., 2019). Negim et al. (2010) found that the BS additions increased soil $\mathrm{pH}$ and conductivity, while immobilized $\mathrm{Cu}, \mathrm{Zn}, \mathrm{Cr}$ and $\mathrm{Cd}$ in the studied contaminated acid soil, which reflected on Phaseolus vulgaris L. growth. Also, Ning et al. (2016) reported that BS was an effective amendment for soil acidity adjustment, plant $\mathrm{Si}$ nutrition and stabilization of $\mathrm{Cd}$ in acidic soils.

Humic acid (HA) is a common fertilizer containing most elements that improve soil fertility and increase nutrients availability, thus enhances plant growth, and yield as well as decreases the harmful effect of stresses (Doran et al., 2003). The effect of HA on the availability of $\mathrm{P}$ and micronutrients in calcareous soils have been given especial attention because of observed increases in uptake rates of these nutrients following application of HA (Satisha \& Devarajan, 2005; Elhag et al., 2019). Also, compost is seen to be beneficial in improving soil fertility and crop productivity (Adugna, 2016), remediating polluted environment, recycling agricultural wastes (Taiwo, 2011), reducing the phytotoxicity of heavy metals (Huang et al., 2016), increasing water use efficiency (Adugna, 2016), and microbial activity (Huang et al., 2016; Lee et al., 2019). In addition, organic chelating agents such as EDTA and citric acid, significantly enhance element solubility and uptake by plants (Afshan et al., 2015), and are commonly used as they are more effective in chelating elements and increasing their concentrations in the upper plant organs (Kanwal et al., 2014).

Bio-fertilizers are playing a vital role in sustainable agricultural management to reduce environmental contamination (Bulut, 2013). Bacillus megaterium var. phosphaticum, which is considered a rhizobacteria, can exert a positive effect on plant growth through solubilizing inorganic phosphate and mineralizing organic phosphate, helping $\mathrm{P}$ to be readily available to plants with time (Abd-Elrahman, 2016; Saxena et al., 2020). Due to the P solubilization capacity, B. megaterium var. phosphaticum could be used along with RP or any other natural source to raise their efficiency in the soil. These cells can produce amino acids, vitamins, indole acetic acid (IAA), gibberellic acids, antibiotics, siderophore, as well as organic and inorganic acids that mobilize $\mathrm{P}$ and other nutrients and encourage the plant growth (Cakmakci et al., 1999; Amalraj et al., 2012). In addition, for the mineralization of organic $\mathrm{P}$ compounds, it could be due to the release of phosphatase enzymes (Illmer et al., 1995; Płaza et al., 2021).

So, the aim of this work was to conduct laboratory and greenhouse experiments to study the effect of using $P$ solubilizing substances and rhizobacteria to solubilize $P$ from different sources. The effect of these treatments on the P-availability in calcareous soils and P- uptake by faba bean plants (Vicia faba 'Giza 843') were also studied.

\section{MATERIALS AND METHODS}

The current study involves two trial types:

\subsection{INCUBATION EXPERIMENT}

To assess $\mathrm{P}$ content in a pure media (any salts, 
$\mathrm{CaCO}_{3}$ and $\mathrm{P}$ were removed) treated by several scarce soluble materials, $200 \mathrm{~g}$ of acid $\left(\mathrm{HCl} 10^{-4} \mathrm{M}\right)$ washed quartz sand were placed in a plastic bowl, kept at the laboratory conditions $\left(24 \pm 2.5^{\circ} \mathrm{C}\right)$. Thirty combinations generated from application of fifteen treatments either without adding bacteria or in the presence of dissolving bacteria (Bacillus megaterium var. phosphaticum) as follows were tested with three replications:

1- Ordinary Superphosphate (OSP)

2- OSP + Compost $1 \%$

3- OSP + Humic acid $1 \%$

4- OSP + Citric acid $1 \%$

5- OSP + EDTA $1 \%$

6- Rock Phosphate (RP)

7- RP + Compost $1 \%$

8- RP + Humic acid $1 \%$

9- RP + Citric acid $1 \%$

10- RP + EDTA $1 \%$

11- Basic Slag (BS)

12- BS + Compost $1 \%$

13- BS + Humic acid $1 \%$

14- BS + Citric acid $1 \%$

15- BS + EDTA $1 \%$

Extractable P concentration in each treatment and total element concentrations in basic slag were measured before adding to the soil. The P sources, i.e., ordinary superphosphate (OSP), rock phosphate (RP) and basic slag (BS), were added at a rate of $4.0 \mathrm{~g} \mathrm{~kg}^{-1}$ sand (equal to $9.6 \mathrm{tha}^{-1}$ ). To meet the proper requirements as recommended by the Egyptian Ministry of Agriculture for faba bean cultivation in newly reclaimed soils (55.8 $\mathrm{kg} \mathrm{P}_{2} \mathrm{O}_{5} \mathrm{ha}^{-1}$ in the form of ordinary superphosphate). Each of rock phosphate granules fertilizer (obtained from Abou Zaabal Company) and basic slag (obtained from Iron and Steel Company in Helwan) were ground to pass through a $2.0 \mathrm{~mm}$ sieve. According to the treatment, $20 \mathrm{ml} \mathrm{bowl}^{-1}$ of Bacillus megaterium var. phosphaticum bacterial suspension, 1 x $10^{9}$ cells $\mathrm{ml}^{-1}$, (supplied by the Department of Microbiology, Faculty of Agriculture, Ain Shams University) were added. Tap water was added to keep the moisture of the medium at the field capacity till the end of the incubation period.

Sand samples (20 $\left.\mathrm{g} \mathrm{bowl}^{-1}\right)$ were taken 3 times; after 2, 4 and 8 weeks. The collected samples were air dried, crushed, sieved to pass through a $2.0 \mathrm{~mm}$ sieve, and prepared to determine available $\mathrm{P}$ spectrophotometrically using Olsen extract $\left(0.5 \mathrm{M} \mathrm{NaHCO}_{3}\right.$ at $\mathrm{pH}$ 8.5 ) according to the method described by Watanabe \& Olsen (1965).

\subsection{POT EXPERIMENT}

A pot experiment was carried out in autumn season of 2019 at the greenhouse of Soil Science Department, Faculty of Agriculture, Ain Shams University, Qalubia governorate, Egypt. The experiment was kept in air temperature $\left(21.9 \pm 3.8^{\circ} \mathrm{C}\right)$. Representative soil samples were collected from the surface layers (0-20 $\mathrm{cm}$ ) of a calcareous soil, Typic Torripsamments (according to Soil Survey Staff, 2010), sandy loam soil from El-

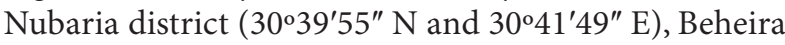
governorate, Egypt. The polythene lined pots $(18 \mathrm{~cm}$ in diameter and $15 \mathrm{~cm}$ in height) were packed uniformly with $3.0 \mathrm{~kg}$ of the investigated soil which was already air dried and ground to pass through a $2.0 \mathrm{~mm}$ sieve. Some initial physical and chemical properties of the studied soil were tested before plant cultivation according to the standard methods outlined by Page et al. (1982) and Klute (1986). The abovementioned 15 treatments plus 4 solubilizing agents' treatments (compost, humic acid, citric acid and EDTA) and their 6 combinations (compost+ humic acid, citric acid+ EDTA, compost+ citric acid, compost+ EDTA, humic acid+ citric acid and humic acid+ EDTA) were added to the pots and mixed well with the soil during packing, with the same doses. Two control (check) treatments were also applied (one for soil free of $\mathrm{P}$ sources and without adding bacteria, and the other for soil free of $\mathrm{P}$ sources in the presence of dissolving bacteria). Tap water was used to keep the moisture of the soil before and after plant cultivation at the field capacity till the end of the experimental work.

After one week from adding the treatments, pots were cultivated with faba bean seeds (Vicia faba 'Giza 843 ', 5 seeds pot $^{-1}$ ) on $16^{\text {th }}$ of October 2019. At the same time, according to the treatment, $20 \mathrm{ml} \mathrm{pot}^{-1}$ of Bacillus megaterium var. phosphaticum bacterial suspension $\left(1 \times 10^{9}\right.$ cells $\left.\mathrm{ml}^{-1}\right)$ were added. After seeds germination, plants were thinned to one plant pot $^{-1}$. Nitrogen fertilizer in the form of $\left(\mathrm{NH}_{4}\right)_{2} \mathrm{SO}_{4}$ and potassium in the form of $\mathrm{K}_{2} \mathrm{SO}_{4}$ were applied, at a rate of $1.0 \mathrm{~g} \mathrm{~kg}^{-1}$ soil (equal to $2.4 \mathrm{t} \mathrm{ha}^{-1}$ ) for each, in two batches the first one at the vegetative growth stage, 60 days after sowing (DAS), and the other one at the flowering stage (90 DAS).

\subsection{MEASUREMENTS}

\subsubsection{Soil P content}

Soil in the investigated pots was sampled 4 times: (i) after seeds germination (14 DAS), (ii) at the vegetative growth stage (60 DAS), (iii) at the flowering stage (90 DAS), and (iv) at plant harvest (145 DAS). The col- 
lected samples were air dried, crushed, sieved through a $2.0 \mathrm{~mm}$ sieve, and prepared to determine available $\mathrm{P}$ spectrophotometrically using Olsen extract, as described by Watanabe \& Olsen (1965).

\subsubsection{Crop traits}

Plants were harvested on the second week of March 2020 , to assess plant height, plant fresh and dry mass, as well as number of pods plant ${ }^{-1}$, fresh mass of pods and seeds plant ${ }^{-1}$. Also, samples of plant leaves were oven dried at $70{ }^{\circ} \mathrm{C}$ for $48 \mathrm{~h}$ and digested by $\mathrm{H}_{2} \mathrm{SO}_{4} /$ $\mathrm{H}_{2} \mathrm{O}_{2}$ mixture according to the method described by Chapman \& Pratt (1961). Total nitrogen in leaves was determined using Kjeldahl method according to the procedure described by Chapman \& Pratt (1961), total phosphorus was determined using Spectrophotometer according to Watanabe \& Olsen (1965) and total potassium in plant leaves was determined using Flame photometer as described by Chapman \& Pratt (1961).

\subsection{EXPERIMENTAL DESIGN AND STATISTICAL ANALYSIS}

The two experiments (incubation and pot experiments) were designed in a completely randomized de-

Table 1a: Extractable- $\mathrm{P}$ in some of the studied treatments

\begin{tabular}{ll}
\hline Treatment & $\mathrm{P}, \mu \mathrm{g} \mathrm{g}^{-1}$ \\
\hline Available form in: & \\
OSP & 60.4 \\
RP & 21.6 \\
BS & 11.2 \\
Compost & 19.5 \\
Humic acid & 32.0 \\
Mixtures $(1: 1, v / v)$ & \\
Citric acid $1 \%+$ OSP $(1: 5)$ & 133 \\
Citric acid 1\%+ RP $(1: 5)$ & 47.0 \\
Citric acid $1 \%+$ BS $(1: 5)$ & 30.7 \\
EDTA 1 \% + OSP (1:5) & 125 \\
EDTA 1 $\%+$ RP $(1: 5)$ & 42.5 \\
EDTA $1 \%+$ BS (1:5) & 32.0 \\
\hline
\end{tabular}

sign and each treatment was replicated three times. The obtained data were then statistically analyzed using SAS software package (SAS, 2000). Values expressed as mean and were compared for each other using Duncan's multiple range test (at $p \leq 0.05$ considered significant) \pm standard error of the mean (SEM, $\mathrm{n}=3)$.

\section{RESULTS AND DISCUSSION}

\subsection{INITIAL CHARACTERISTICS OF SOIL AND TREATMENTS}

Extractable P concentration in each treatment before adding to the investigated soil are shown in Table 1a. The treatment of OSP is rich with $\mathrm{P}$, followed by humic acid, RP, compost and BS respectively. Regarding the mixtures between treatments (Table 1a), the treatment of citric acid+ OSP gave high concentration of soluble $\mathrm{P}$, followed by EDTA+ OSP, citric acid+ RP, EDTA + RP, EDTA + BS and citric acid+ BS respectively. Total element concentrations in basic slag were measured before adding to the soil (Table $1 \mathrm{~b}$ ). It seems good that finding appreciable amounts of $\mathrm{P}, \mathrm{Mg}, \mathrm{S}, \mathrm{Fe}$, Mn, B and other elements in BS. Some initial physical (soil texture, field capacity, wilting point, and saturation percent) and chemical $\left(\mathrm{CaCO}_{3}\right.$ fractions content, organic matter content, soil cation exchange capacity, $\mathrm{pH}$, electrical conductivity of salts, soluble ions concentration, total and available concentration of macronutrients NPK) properties of the studied soil before plant cultivation are presented in Table 2 . The studied soil is calcareous sandy loam with no saline hazards and low macronutrients concentration.

\subsection{INCUBATION EXPERIMENT}

Data in Table 3 shows the availability of $\mathrm{P}$ concentrations in acid washed sand with time; after applying different P- sources and solubilizing agents, with or without adding $\mathrm{P}$ dissolving bacteria. As $\mathrm{P}$ fertilizers (OSP, RP and BS) which vary in their P contents were added to washed sand at equal rates $\left(4 \mathrm{~g} \mathrm{~kg}^{-1}\right)$, the extractable amounts in washed sand were significantly different between all sources after 2 weeks. With time, the soluble amounts of $\mathrm{P}$ increased to about 4 times at 4 weeks then dropped to about the values of the first pe-

Table 1b: Total elements concentration in the basic slag sample

\begin{tabular}{|c|c|c|c|c|c|c|c|c|c|c|c|c|}
\hline Element & $\mathrm{P}$ & $\mathrm{K}$ & $\mathrm{Ca}$ & $\mathrm{Mg}$ & $\mathrm{S}$ & $\mathrm{Fe}$ & $\mathrm{Mn}$ & $\mathrm{Si}$ & $\mathrm{Al}$ & $\mathrm{Cr}$ & $\mathrm{B}$ & Mo \\
\hline Concentration, $\%$ & 0.55 & 0.08 & 32.1 & 5.40 & 0.06 & 19.5 & 2.32 & 7.02 & 1.32 & 0.06 & 0.02 & $<0.01$ \\
\hline
\end{tabular}


Table 2: Some initial physical and chemical characteristics of the surface layer of the experimental soil $(0-20 \mathrm{~cm})$ before plant cultivation

\begin{tabular}{|c|c|c|c|}
\hline \multicolumn{2}{|l|}{ Particle size distribution, $\%$} & \multicolumn{2}{|l|}{ Soluble cations, mmol $_{c} 1^{-1}$} \\
\hline Sand & 65.8 & $\mathrm{Ca}^{2+}$ & 10.2 \\
\hline Silt & 20.3 & $\mathrm{Mg}^{2+}$ & 6.34 \\
\hline Clay & 13.9 & $\mathrm{Na}^{+}$ & 1.11 \\
\hline Textural class & Sandy loam & $\mathrm{K}^{+}$ & 0.52 \\
\hline $\mathrm{FC}, \%$ & 12.3 & Soluble anions, $\operatorname{mmol}_{c} \mathrm{l}^{-1}$ & \\
\hline WP, \% & 4.20 & $\mathrm{CO}_{3}^{2-}$ & n.d.* \\
\hline SP, $\%$ & 31.5 & $\mathrm{HCO}_{3}^{-}$ & 4.27 \\
\hline $\mathrm{CaCO}_{3}$ fractions, $\%$ & & $\mathrm{Cl}^{-}$ & 2.49 \\
\hline Coarse sand & 16.8 & $\mathrm{SO}_{4}^{2-}$ & 6.28 \\
\hline Fine sand & 8.30 & Total macronutrients, $\%$ & \\
\hline Silt & 6.10 & $\mathrm{~N}$ & 0.01 \\
\hline Clay & 5.30 & $\mathrm{P}$ & 0.01 \\
\hline $\mathrm{CaCO}_{3}, \mathrm{~g} \mathrm{~kg}^{-1}$ & 365 & $\mathrm{~K}$ & 0.02 \\
\hline $\mathrm{OM}, \mathrm{g} \mathrm{kg}^{-1}$ & 1.10 & Available macronutrients, $\mu \mathrm{g} \mathrm{g}^{-1}$ & \\
\hline $\mathrm{CEC}, \mathrm{cmol}_{\mathrm{c}} \mathrm{kg}^{-1}$ & 11.7 & $\mathrm{~N}$ & 12.3 \\
\hline pH (1:2.5 soil:water suspension) & 8.06 & $\mathrm{P}$ & 1.00 \\
\hline$\underline{\mathrm{EC}_{\mathrm{e}}, \mathrm{dS} \mathrm{m}^{-1}}$ & 0.99 & $\mathrm{~K}$ & 92.6 \\
\hline
\end{tabular}

${ }^{\star}$ n.d. means not detected, field capacity (FC), wilting point (WP), saturation percent (SP), organic matter content in soil (OM), cation exchange capacity (CEC), and electrical conductivity of salts in soil extract $\left(\mathrm{EC}_{\mathrm{e}}\right)$

riod for the various $\mathrm{P}$ - sources. It also appears that the P solubility increased to about 5-6 times for all sources in the presence of the added bacteria compared to the treatments without adding $\mathrm{P}$ dissolving bacteria.

With respect to the effect of the natural compounds (compost and humic acid), there was a slight increase in P solubility of the three sources when compost was added. Also, the same results were found when humic acid was added, but for OSP the P solubility increased more than the double. These results agreed with those obtained by Elhag et al. (2019) concerning the effect of humic acid on increasing $\mathrm{P}$ availability in washed sand. On the other hand, the effect of these natural organic sources was different when the dissolving bacteria was added, as the values of $P$ solubility increased with compost or humic acid in these sources with more $\mathrm{P}$ solubility for OSP than for RP or BS. This could be related to increasing the activity of the dissolving bacteria in the presence of organic sources. The bacteria decompose these compounds to simple materials beside the materials excreted by the bacteria. All these new compounds act in dissolving the P- sources. The effect was almost double in the OSP treatment than with RP or BS treatments. These results agreed with those obtained by Abd-Elrahman (2016) about the effect of P dissolv- ing bacteria on the solubility of $\mathrm{P}$ from OSP and RP fertilizers.

Results of the ability of humic acid (HA) added or formed from the decomposition of compost or any simple or complex organic compounds resulted from the action of the bacteria added could be explained on the bases that these compounds may have positive or negative charges. The positive charges bind $\mathrm{PO}_{4}^{3-}$ groups, so help in releasing the phosphate from the insoluble sources. On the other hand, the negative charge can bind $\mathrm{Ca}^{2+}$ ion or any cation, so, also, helps in releasing the phosphate group from the insoluble sources (Campitelli et al., 2003).

Regarding to the action of citric acid and EDTA, results show that in the absence of dissolving bacteria these compounds were superior to the compost and humic acid as they play their role directly without the action of the bacteria. This was clear with the insoluble sources RP and BS. The following descending order generally appeared in the chemically extractable mount of $\mathrm{P}$ with addition of solubilizing agents: citric acid $>$ EDTA $>$ HA $>$ compost for these sources of P. Mihoub et al. (2018) reported that after a period of 960 $\mathrm{h}$ from incubation of highly calcareous soil samples $\left(50 \% \mathrm{CaCO}_{3}\right)$ fertilized with triple superphosphate 
and mono-ammonium phosphate and treated with citric acid and oxalic acid solutions, treatments showed a significant decrease in extractable $\mathrm{P}$ with time, however, applying these solutions exerted a very favorable effect on P solubility in soil. Also, in our study, with the addition of dissolving bacteria to the studied treatments activated the bacteria in dissolving the insoluble sources beside binding phosphate groups. Results also indicate that in the absence of dissolving bacteria, the soluble phosphates decrease by increasing the time of incubation at 8 weeks. But in the presence of dissolving bacteria the values in most treatments remain stable at 8 weeks. This clearly indicates that the compound formed in the presence of bacteria were more stable than that in the absence of bacteria. Abd-Elrahman (2016) reported that $\mathrm{P}$ dissolving bacteria increases $\mathrm{P}$ availability from OSP, and RP fertilizers added to a calcareous soil, with time.

\subsection{POT EXPERIMENT}

\subsubsection{Available $\mathrm{P}$ in soil}

Table 4 shows the effect of different $\mathrm{P}$ sources and solubilizing agents on available $\mathrm{P}$ in calcareous soil in the presence or absence of $\mathrm{P}$ dissolving bacteria, during the physiological stages of faba bean growth. Results indicate that the values ranged from 1.2 to $10.4 \mu \mathrm{g} \mathrm{g}^{-1}$ in the absence of bacteria, and from 3.4 to $29.8 \mu \mathrm{g} \mathrm{g}^{-1}$ in the presence of bacteria. The solubility of $\mathrm{P}$ sources differs in their ability to release soluble $\mathrm{P}$ in the following order: OSP > RP > BS. In fact, this is related to their difference in their content of total- and extractable- $\mathrm{P}$ amounts. With respect to the ability of solubilizing agents in releasing $\mathrm{P}$ in the soil, it appears that they differ in the following descending order: citric acid $>$ EDTA $>\mathrm{HA}>$ compost, similar to that found in the incubation experiment. As these agents were applied at the rate of $1 \%$ $(\mathrm{w} / \mathrm{w})$, so it is expected that the active material of citric acid will be more than in compost and humic acid, as humus is composed of simple and complex compost as lignin (Taiwo, 2011). The superiority of citric acid compared to EDTA, could be explained on the basis that citric acid is smaller molecule compared to EDTA, so the active molecule well be more in $1 \%$ of the material added compared to EDTA (Kanwal et al., 2014; Afshan et al., 2015). Besides the ability of EDTA to react with $\mathrm{Ca}$ to release $\mathrm{P}$ in the soil, it can chelate elements as $\mathrm{Mg}, \mathrm{Fe}, \mathrm{Mn}$ and $\mathrm{Pb}$ with higher stability (Hamed \& Gamal, 2014; Kanwal et al., 2014). This may be the reason

Table 3: Effect of the studied treatments on chemically available $\mathrm{P}\left(\mu \mathrm{g} \mathrm{g}^{-1}\right)$ in washed sand with time, in the presence or absence of P- dissolving bacteria

\begin{tabular}{lllllll}
\hline & \multicolumn{5}{c}{ Available P in washed sand $\left(\mu \mathrm{g} \mathrm{g}^{-1}\right)$} \\
\cline { 2 - 7 } Treatment & \multicolumn{5}{c}{ Without adding bacteria } & In the presence of dissolving bacteria \\
\cline { 2 - 7 } OSP & after 2 weeks & 4 weeks & 8 weeks & after 2 weeks & 4 weeks & 8 weeks \\
OSP + Compost 1\% & $1.00 \pm 0.03 \mathrm{hi}$ & $4.20 \pm 0.12 \mathrm{hi}$ & $0.80 \pm 0.04 \mathrm{i}$ & $6.40 \pm 0.11 \mathrm{f}$ & $24.4 \pm 1.92 \mathrm{~d}$ & $25.0 \pm 2.14 \mathrm{~d}$ \\
OSP + Humic Acid 1\% & $1.80 \pm 0.04 \mathrm{~g}$ & $5.80 \pm 0.15 \mathrm{f}$ & $1.60 \pm 0.06 \mathrm{~g}$ & $7.60 \pm 0.13 \mathrm{~d}$ & $24.6 \pm 2.02 \mathrm{~cd}$ & $25.6 \pm 2.19 \mathrm{c}$ \\
OSP + Citric Acid 1\% & $4.00 \pm 0.14 \mathrm{c}$ & $10.6 \pm 0.26 \mathrm{c}$ & $1.80 \pm 0.06 \mathrm{f}$ & $8.20 \pm 0.16 \mathrm{c}$ & $24.8 \pm 2.03 \mathrm{bc}$ & $25.0 \pm 2.10 \mathrm{~d}$ \\
OSP + EDTA 1\% & $9.40 \pm 0.21 \mathrm{a}$ & $12.8 \pm 0.28 \mathrm{a}$ & $13.2 \pm 0.17 \mathrm{a}$ & $13.8 \pm 0.23 \mathrm{a}$ & $54.6 \pm 2.54 \mathrm{a}$ & $57.6 \pm 2.64 \mathrm{a}$ \\
RP & $6.80 \pm 0.19 \mathrm{~b}$ & $11.0 \pm 0.26 \mathrm{c}$ & $4.60 \pm 0.09 \mathrm{~b}$ & $11.4 \pm 0.17 \mathrm{~b}$ & $25.0 \pm 2.11 \mathrm{~b}$ & $27.4 \pm 2.23 \mathrm{~b}$ \\
RP + Compost 1 \% & $0.80 \pm 0.03 \mathrm{i}$ & $3.80 \pm 0.10 \mathrm{ij}$ & $0.60 \pm 0.05 \mathrm{j}$ & $6.20 \pm 0.10 \mathrm{f}$ & $10.2 \pm 0.21 \mathrm{j}$ & $10.2 \pm 0.19 \mathrm{j}$ \\
RP + Humic Acid 1\% & $1.00 \pm 0.03 \mathrm{hi}$ & $5.20 \pm 0.14 \mathrm{~g}$ & $1.40 \pm 0.06 \mathrm{~h}$ & $6.40 \pm 0.12 \mathrm{f}$ & $11.4 \pm 0.25 \mathrm{~h}$ & $10.8 \pm 0.22 \mathrm{hi}$ \\
RP + Citric Acid 1 \% & $1.60 \pm 0.04 \mathrm{~g}$ & $5.60 \pm 0.15 \mathrm{f}$ & $1.40 \pm 0.07 \mathrm{~h}$ & $6.80 \pm 0.12 \mathrm{e}$ & $12.2 \pm 0.26 \mathrm{f}$ & $12.6 \pm 0.29 \mathrm{f}$ \\
RP + EDTA 1 \% & $3.60 \pm 0.11 \mathrm{~d}$ & $12.0 \pm 0.27 \mathrm{~b}$ & $3.80 \pm 0.08 \mathrm{c}$ & $7.00 \pm 0.13 \mathrm{e}$ & $12.6 \pm 0.27 \mathrm{e}$ & $11.6 \pm 0.23 \mathrm{~g}$ \\
BS & $3.00 \pm 0.12 \mathrm{e}$ & $6.80 \pm 0.17 \mathrm{e}$ & $3.60 \pm 0.07 \mathrm{~d}$ & $7.60 \pm 0.15 \mathrm{~d}$ & $11.8 \pm 0.26 \mathrm{~g}$ & $13.0 \pm 0.26 \mathrm{e}$ \\
BS + Compost 1 \% & $0.40 \pm 0.02 \mathrm{j}$ & $3.40 \pm 0.11 \mathrm{j}$ & $0.40 \pm 0.03 \mathrm{k}$ & $4.40 \pm 0.08 \mathrm{k}$ & $8.60 \pm 0.14 \mathrm{k}$ & $9.00 \pm 0.08 \mathrm{k}$ \\
BS + Humic Acid 1\% & $1.00 \pm 0.03 \mathrm{hi}$ & $4.60 \pm 0.13 \mathrm{~h}$ & $0.60 \pm 0.04 \mathrm{j}$ & $4.80 \pm 0.08 \mathrm{j}$ & $10.3 \pm 0.22 \mathrm{ij}$ & $10.6 \pm 0.21 \mathrm{i}$ \\
BS + Citric Acid 1\% & $1.20 \pm 0.03 \mathrm{~h}$ & $5.20 \pm 0.15 \mathrm{~g}$ & $0.80 \pm 0.06 \mathrm{i}$ & $5.20 \pm 0.09 \mathrm{i}$ & $10.4 \pm 0.22 \mathrm{i}$ & $11.4 \pm 0.23 \mathrm{~g}$ \\
BS + EDTA 1 \% & $3.40 \pm 0.14 \mathrm{~d}$ & $9.60 \pm 0.25 \mathrm{~d}$ & $3.60 \pm 0.08 \mathrm{~d}$ & $5.40 \pm 0.09 \mathrm{hi}$ & $10.4 \pm 0.24 \mathrm{i}$ & $11.0 \pm 0.22 \mathrm{~h}$ \\
\hline
\end{tabular}

Ordinary Superphosphate (OSP), Rock Phosphate (RP), Basic Slag (BS). Values expressed as mean \pm SE, the significant value was set at $p \leq 0.05$. Different letters indicate significant difference between treatments. 
why extractable P from the treated soil with EDTA was less than citric acid. Mihoub et al. (2016) found that organic acids, i.e., citric acid and oxalic acid, decreased $\mathrm{P}$ sorption capacity on the investigated calcareous soil whereas increased Gibbs free energy $(\Delta G)$ of $\mathrm{P}$ which reflected on increasing its solubility in soil, however, with citric acid more than oxalic acid.

It appears that, as a function of time with growing the faba bean plants, extractable P decreased with time for the three $\mathrm{P}$ sources added alone and when compost and humic acid were added. This is related to activity of plant roots to utilize and withdraw the soluble $\mathrm{P}$ to fulfill the plant requirements. Also, it probably due to refixation of soluble $\mathrm{P}$ in soil by released $\mathrm{Ca}$ or another cation. In addition, data of extractable $\mathrm{P}$ in the presence of bacteria were significantly higher compared when bacteria were not added, and still the sequence was as follow: OSP $>$ RP $>$ BS. The reason for remaining BS in the last order may be due to its low $\mathrm{P}$ content. Yildirim \& Prezzi (2011) reported that BS is containing small amounts of total $\mathrm{P}$ in the form of $\mathrm{P}_{2} \mathrm{O}_{5}$ ranged from 0.01 to $3.3 \%$ in all different types.

Regarding the combinations between organic substances and chelating agents, the treatment of $\mathrm{HA}+$ citric acid was superior in giving high extractable amount of $\mathrm{P}$ in soil, followed by HA+ EDTA in most physiological stages of growing bean plants, with significant differences in the presence of added bacteria. Humic acid plays a vital role in increasing $P$ availability in soil (Doran et al., 2003; Sahin et al., 2014), plus its considerable content of $\mathrm{P}$ (Table 1a). Citric acid, in addition to decrease soil $\mathrm{pH}$, it makes complexes with $\mathrm{Ca}$ forming calcium citrate and releasing $\mathrm{P}$ in soluble form in the soil (Drouillon \& Merckx, 2003). EDTA may solubilize the insoluble $\mathrm{P}$ forms in calcareous soils by chelating $\mathrm{Ca}^{2+}$ and $\mathrm{Mg}^{2+}$ cations, lowering soil $\mathrm{pH}$ and/ or the partial occupation of active anionic groups on the surface of $\mathrm{CaCO}_{3}$ and clay minerals (Hamed \& Gamal, 2014). It appears that the presence of bacteria played a protective role against P- fixation (Abd-Elrahman, 2016; Płaza et al., 2021).

\subsubsection{Vegetative growth parameters}

Data in Table 5 shows the effect of the studied Ptreatments on faba bean plant height, and plant fresh and dry mass, in the presence or absence of P- dissolving bacteria. The data of plant dry mass indicate that the addition of P-sources increased the dry mass yield more than the control and the rate of increase was in the same sequence mentioned for $\mathrm{P}$ availability in the soil: OSP $>$ RP $>$ BS (Table 4). The role of $\mathrm{P}$ in enhancing roots growth and their absorption efficiency in the soil was observed, which reflected on the plant growth and its yield. Razaq et al. (2017) found that applying P fertilizer increased root surface area, specific root length and root-shoot ratio. Fouda (2017) confirmed the effect of $\mathrm{P}$ fertilizer on increasing faba bean productivity.

With respect to the effect of solubility agents, the sequence was different: EDTA > citric acid > HA > compost for OSP and RP, but the values were almost the same for BS. This indicates that despite relatively low total $\mathrm{P}$ content in BS (Table $1 \mathrm{~b}$ ), the $\mathrm{P}$ is found in a form easily released by the solubilizing agents. The addition of solubilizing bacteria increased the yield of dry mass to the extend to record slight significant difference between the studied P- sources. This was also found when comparing the effect of solubilizing agents on yield in case of RP and BS were almost the same. Such soil with its high content of $\mathrm{CaCO}_{3}$ is characterized by deficiency problems with some elements, particularly the micronutrients. The presence of appreciable amounts of $\mathrm{Fe}$, $\mathrm{Mn}, \mathrm{Mg}, \mathrm{S}, \mathrm{B}$ and other elements in BS had an effect of plant growth despite the low $\mathrm{P}$ content added (Table 1b).

It is interesting to note that the highest yield recorded for this experiment was when EDTA was added to OSP treatment, or mixed with HA, in the presence of P- dissolving bacteria. The above results indicate that solubilizing agents and dissolving bacteria not only act in solubilizing P from added materials and from soil, but also act in solubilizing other elements as Fe, Mn and $\mathrm{Mg}$ which are essential for plant growth. EDTA is known to chelate elements as $\mathrm{Fe}, \mathrm{Mn}, \mathrm{Zn}$ and $\mathrm{Mg}$ with higher stability as compared to citric acid or natural compounds as humic acid (Hamed \& Gamal, 2014).

Similar trend was observed with the other vegetative growth parameters of faba bean plants as affected by the studied $\mathrm{P}$ treatments, with significant effect in the presence of $\mathrm{P}$ - dissolving bacteria as compared to not adding bacteria. Plant height ranged from $25 \mathrm{~cm}$ (in control treatment, without adding $\mathrm{P}$ sources and dissolving bacteria) to $70 \mathrm{~cm}$ (with applying the treatment of HA combined with EDTA, in the presence of dissolving bacteria). Also, the plant fresh mass ranged from $22.8 \mathrm{~g} \mathrm{plant}^{-1}$ in control treatment (without any additions) to $60.5 \mathrm{~g} \mathrm{plant}^{-1}$ with applying the treatment of HA combined with EDTA, in the presence of P- dissolving bacteria.

\subsubsection{Numbers of pods plant ${ }^{-1}$, fresh mass of pods plant $^{-1}$ and fresh mass of faba bean seeds plant ${ }^{-1}$}

Results of mass of seeds (g plant ${ }^{-1}$ ) shown in Table 


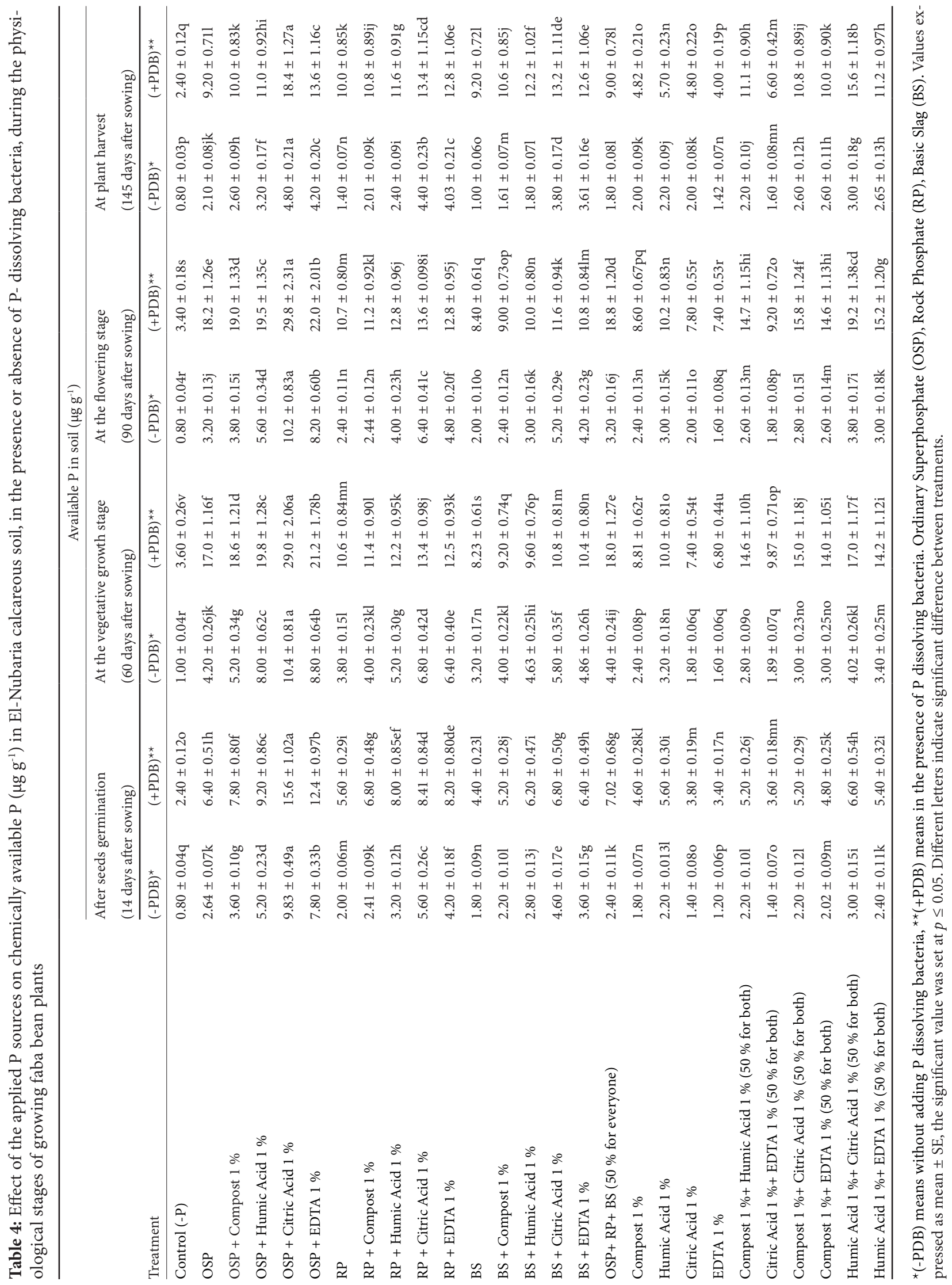




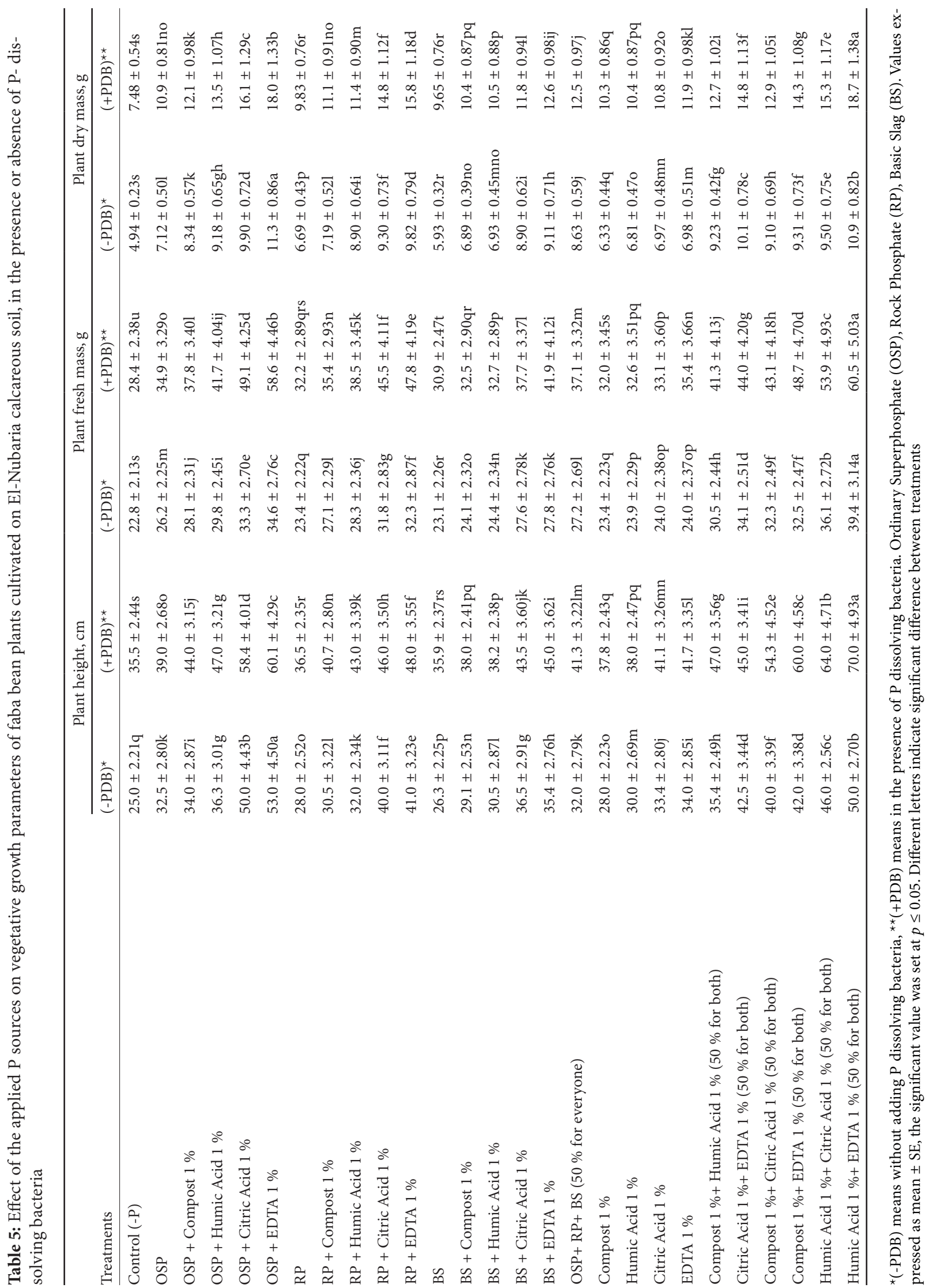


6 indicates the values ranged between $1.21 \mathrm{~g}$ to $11.5 \mathrm{~g}$ with lower values for treatments without bacteria addition. The addition of $\mathrm{P}$ fertilizers significantly increased the seed yield by about 5 times with OSP and only about 3 times for RP and BS compared to the control without bacteria addition. When solubilizing bacteria was added the magnitude of increase was only about the double in case of OSP and slightly less than double in case of RP and BS. This means that the solubilizing bacteria play a major role than the P- sources. Bacillus megaterium var. phosphaticum produced acids that enhanced the availability of phosphates and increased the uptake of other nutrients, leading to increased yields (Cakmakci et al., 1999; Saxena et al., 2020; Płaza et al., 2021).

With respect to solubilizing agents, there are slight significant difference among solubilizing agents in the absence of bacteria. However, when solubilizing bacteria was added the effect follows the sequence: EDTA > citric acid > HA > compost in case of OSP and RP, but the effect was almost the same when BS was used. This means there are factors other than $\mathrm{P}$ in BS contributed to the production of seeds yield. It is possible that the presence of appreciable amounts of $\mathrm{Mg}, \mathrm{S}, \mathrm{Fe}, \mathrm{Mn}, \mathrm{B}$ and other elements played a role in plant growth, although P percentage was relatively low compared to RP and OSP (Yildirim \& Prezzi, 2011).

Regarding the interaction among the studied treatments, the treatment of HA+ EDTA gave the highest seeds yield, recording 8.57 g plant $^{-1}$ without adding bacteria. While recorded $11.5 \mathrm{~g} \mathrm{plant}^{-1}$ in the presence of added bacteria. Similar trend was found with the other yield parameters, with high significant difference in the presence of P- dissolving bacteria. Number of pods plant ${ }^{-1}$ varied from 1 in control treatment (without any additions) to 6.67 that recorded by many treatments, OSP in combination with citric acid or EDTA and the treatment of HA combined with EDTA, in the presence of P- dissolving bacteria. Regarding the fresh weight of pods, ranged from $2.59 \mathrm{~g} \mathrm{plant}^{-1}$ (in control treatment, without any additions) to $22.3 \mathrm{~g} \mathrm{plant}^{-1}$ with applying the treatment of HA combined with EDTA, in the presence of P- dissolving bacteria (Table 6).

\subsubsection{N, P and $\mathrm{K}$ concentrations in faba bean leaves}

Results of $\mathrm{P}$ concentration in leaves of faba bean plants (Table 7) indicated that by addition of $\mathrm{P}$ sources, $P$ contents increased with remarkable increase with applying OSP treatment than applying RP or BS treatments. This was found in case of without adding or with adding solubilizing bacteria, but the values were generally higher with the later. Elhag et al. (2019) reported that, increasing available $\mathrm{P}$ in soil by addition of $\mathrm{P}$ sources was reflected on increasing $\mathrm{P}$ concentration in bean roots and shoots, with high concentrations in shoots more than roots.

However, no remarkable difference in concentration among solubilizing agents, except when EDTA or citric acid was added with BS. This again clearly indicate the role of these relatively small compounds in solubilizing not only insoluble $\mathrm{P}$, but also other elements as $\mathrm{Mg}, \mathrm{Fe}, \mathrm{Mn}$ in BS which may activate plant roots to absorb nutrients. The enhanced role of EDTA or citric acid in calcareous soils is not only due to acidification of the plant rhizosphere, but also to its $\mathrm{Ca}$ and $\mathrm{Mg}$ complexing capacity (Drouillon \& Merckx, 2003; Hamed \& Gamal, 2014). Mihoub et al. (2019) found that P uptake by wheat plants grown in alkaline calcareous soil was $0.493 \mathrm{mg} \mathrm{P}^{\mathrm{P}}$ pot $^{-1}$ in the control treatment, however, it reached 0.701 and $0.785 \mathrm{mg} \mathrm{Pot}^{-1}$ in the amended pots with pigeon manure juice and citric acid, respectively.

Regarding the interaction between solubilizing agents, the treatment of HA+ EDTA, followed by that plus citric acid gave the highest concentration of $\mathrm{P}$ in plant leaves, with significant difference as compared to the other treatments. Sahin et al. (2014) found that humic substances in interaction with $\mathrm{P}$ in the soil could decrease the P- fixation and increase the P- uptake by plants.

With respect to the effect of the studied treatments on $\mathrm{N}$ and $\mathrm{K}$ concentrations in plant leaves (Table 7), it was clear that the addition of $\mathrm{P}$ increased $\mathrm{N}$ and $\mathrm{K}$ content in all treatments. Also, there was a remarkable difference recorded with respect to the solubilizing agents and bacterial additions. Although HA and compost enhanced the plant uptake from $\mathrm{N}$ and $\mathrm{K}$, due to their considerable content of the macro elements; the treatments of EDTA and citric acid were superior in increasing plant uptake of both. These may be due to enhancing root efficiency in absorbing nutrients from soil and added fertilizers, lowering soil $\mathrm{pH}$, and their high $\mathrm{Ca}$ and $\mathrm{Mg}$ complexing capacity (Drouillon \& Merckx, 2003; Hamed \& Gamal, 2014).

The main problem of the investigated soil is its high content of $\mathrm{CaCO}_{3}(36.5 \%$, Table 2$)$, and this is influence on nutrients availability and uptake by plants. So, the soil moisture content should be kept up to field capacity till the end of the experimental work. Also, the role of EDTA and citric acid in enhancing root growth and absorption, besides their interaction with $\mathrm{CaCO}_{3}$ in soil as well as their effects on lowering soil $\mathrm{pH}$; reflected on enhancing plant growth and productivity, as compared to the effect of compost or HA (Campitelli et al., 2003; Drouillon \& Merckx, 2003). The interac- 


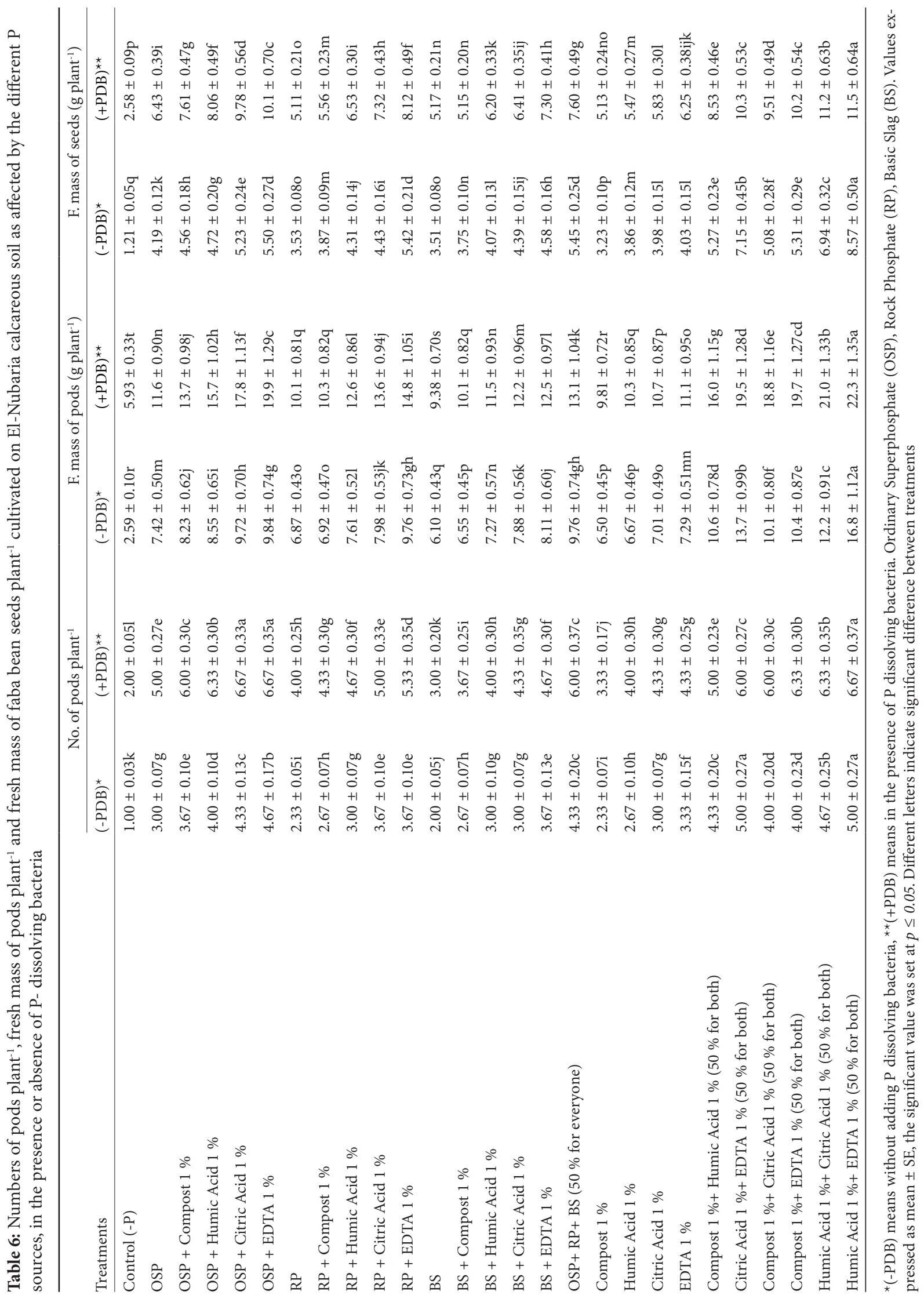




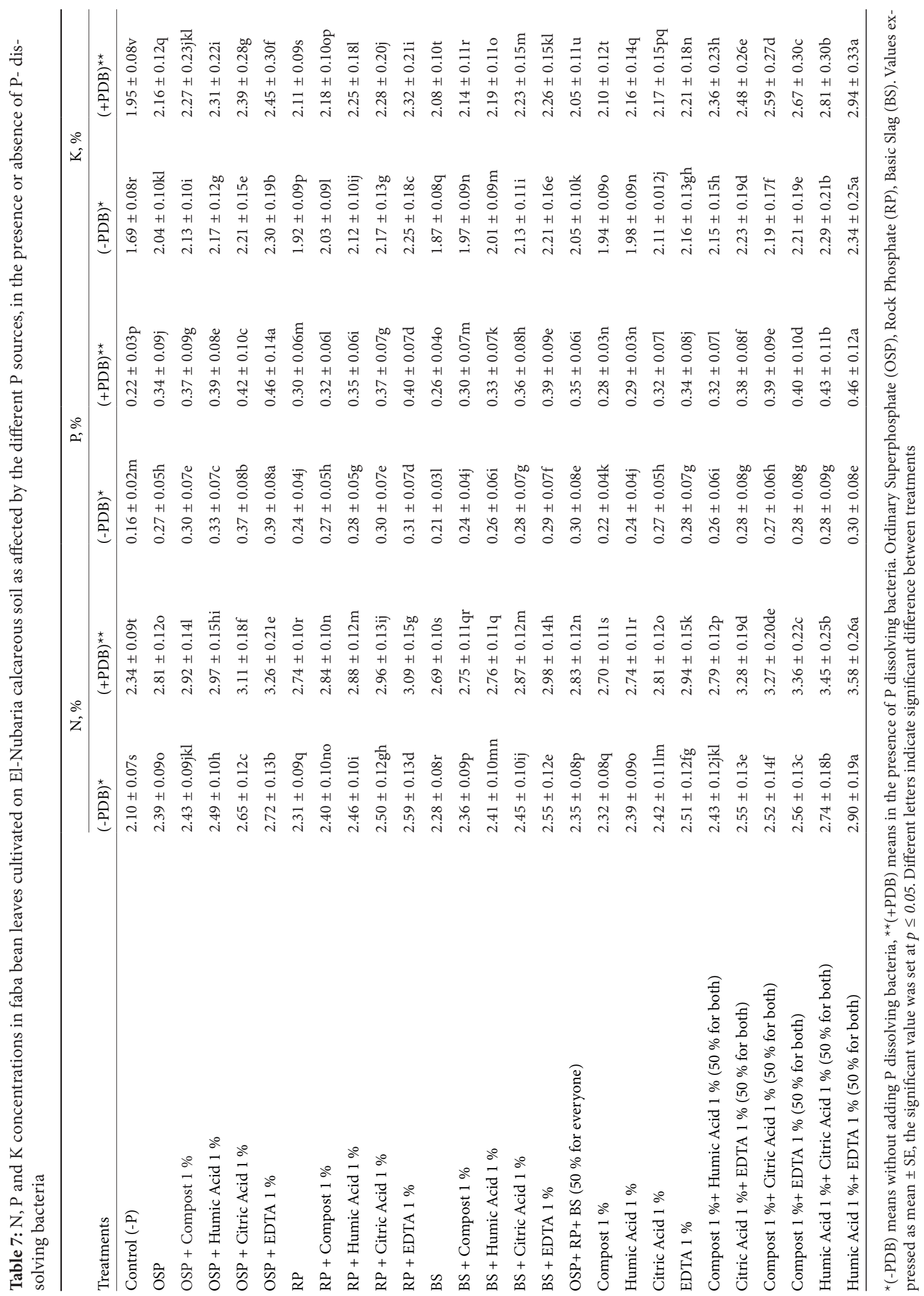


tion among the studied treatments gave better results, especially between chelating agents and organic compounds. In addition, the $\mathrm{P}$ dissolving bacteria produce organic and inorganic acids that mobilize $\mathrm{P}$ and other nutrients and encourage plant growth, as well as releasing phosphatase enzymes to mineralize organic P (Illmer et al., 1995; Cakmakci et al., 1999; Amalraj et al., 2012; Płaza et al., 2021).

\section{CONCLUSION}

Many factors are affecting the solubility of $\mathrm{P}$ in calcareous soils. In our study we tried to use some sources of $\mathrm{P}$ as well as organic substances and chelating agents, the interaction between them being the best. BS gave promising results especially when combined with citric acid and EDTA not only in calcareous soil, but possibly in soils poor in nutrient elements as sandy soils, even under the alkaline conditions. Using BS gained many benefits such as recycling of wastes, protecting the environment from contamination, and being a source of $P$ fertilizer. Also, application of citric acid and EDTA enhanced faba bean growth in the investigated soil, particularly with addition of organic substances. In addition, adding solubilizing bacteria played a major role than the P- sources in enhancing the availability of $\mathrm{P}$ and increasing the uptake of other nutrients, leading to increased yield.

\section{RECOMMENDATIONS}

The use of RP as a source of P in calcareous soil at the time of applying the organic and bio fertilizers and close to plant roots is so beneficial. Applying RP or BS during the preparation of compost will enrich the compost with P. Application of BS along with organic fertilizers and chelating agents can be recommended in low fertile soil as sandy soil.

\section{REFERENCES}

Abd-Elrahman, Shaimaa H. (2016). Effect of unconventional phosphorus sources and phosphate solubilizing bacteria on fractions of phosphorus in a calcareous soil cultivated with wheat plants. International Journal of Plant and Soil Science, 12, 1-11. http://dx.doi.org/10.9734/ IJPSS/2016/28375

Adugna, G. (2016). A review on impact of compost on soil properties, water use and crop productivity. Academic Research Journal of Agricultural Science and Research, 4, 93104.http://dx.doi.org/10.14662/ARJASR2016.010
Afshan, S., Ali, Sh., Bharwana, S., Rizwan, M., Farid, M., \& Abbas, F., et al. (2015). Citric acid enhances the phytoextraction of chromium, plant growth, and photosynthesis by alleviating the oxidative damages in Brassica napus L. Environmental Science and Pollution Research, 22, 11679-89. http://dx.doi.org/10.1007/s11356-015-4396-8

Amalraj, E.L.D., Maiyappan, S., \& Peter, A.J. (2012). In vivo and In vitro studies of Bacillus megaterium var. phosphaticum on nutrient mobilization, antagonism and plant growth promoting traits. Journal of Ecobiotechnology, 4, 35-42.

Bing, L., Biao, T., Zhen, M., Hanchi, Ch., \& Hongbo, L. (2019). Physical and chemical properties of steel slag and utilization technology of steel slag at home and abroad. IOP Conf. Series: Earth and Environmental Science, 242, 1-6. http://dx.doi.org/10.1088/17551315/242/3/032012

Bulut, S. (2013). Evaluation of yield and quality parameters of phosphorous-solubilizing and N-fixing bacteria inoculated in wheat (Triticum aestivum L.). Turkish Journal of Agriculture and Forestry, 37, 545-554. http://dx.doi. org/10.3906/tar-1212-96

Cakmakci, R., Kantar, F., \& Algur, F.(1999).Sugar beet and barley yields in relation to Bacillus polymyxa and Bacillus megaterium var. phosphaticum inoculation. Journal of Plant Nutrition and Soil Science, 162, 437-442. https://doi.org/10.1002/ (SICI) 1522 - 2624(199908) 162:4\%3C437::A ID JPLN437\%3E3.0.CO;2-W

Campitelli, P.A., Velasco, M.I., \& Ceppi, S.B. (2003). Charge development and acid-base characteristics of soil and compost humic acids. Journal of the Chilean Chemical Society, 48(3). http://dx.doi.org/10.4067/S071797072003000300018

Chapman, H.D., \& Pratt, P.F. (1961). Methods of Analysis for Soils, Plants, and Waters. Division of Agric. Sci. Berkeley, Univ. California, USA, pp. 150-152.

Doran, I., Akinci, C., \& Yildirim, M. (2003). Effects of delta humate applied with different doses and methods on yield and yield components of diyarbakir-81 wheat cultivar. $5^{\text {th }}$ Field Crops Congress, Diyarbakir, Turkey, 2, 530-534.

Drouillon, M., \& Merckx, R. (2003). The role of citric acid as a phosphorus mobilization mechanism in highly $\mathrm{P}$ fixing soils. Gayana Botanica, 60(1), 55-62. http://dx.doi. org/10.4067/S0717-66432003000100009

Elgala, A.M., \& Amberger, A. (2017). Factors affecting solubilization of rock phosphates in soils. International Journal of Plant and Soil Science, 14, 1-8. http://dx.doi.org/10.9734/ IJPSS/2017/28526

Elhag, R.S., Elgala, A.M., Elsharawy, M.O., \& Eid, M.A. (2019). Evaluate the effect of some factors affecting solubilization of phosphorus in rhizosphere. Arab Universities Journal of Agricultural Sciences, Ain Shams University, 27, 913-923. https://doi.org/10.21608/ajs.2019.43847

Fouda, K.F. (2017). Effect of phosphorus level and some growth regulators on productivity of faba bean (Vicia faba L.). Egyptian Journal of Soil Science, 57, 73-87.http://dx.doi. org/10.21608/ejss.2017.3593

Grover, R. (2003). Rock phosphate and phosphate solubilizing microbes as a source of nutrients for crops. M.Sc. Thesis, Patiala.

Hamed, M.H., \& Gamal, M.M. (2014). Effect of incubation pe- 
riods and some organic materials on phosphorus forms in calcareous soils. International Journal of Technology Enhancements and Emerging Engineering Research (IJTEEE), 2, 108-118.

Hopkins, B., \& Ellsworth, J. (2005). Phosphorus availability with alkaline/ calcareous soil. Western Nutrient Management Conference, Vol. 6. Salt Lake City, UT, pp. 88-93.

Houassine, D., Latati, M., Rebouh, N.Y., \& Gérard, F. (2020). Phosphorus acquisition processes in the field: Study of faba bean cultivated on calcareous soils in Algeria. Archives of Agronomy and Soil Science, 66, 168-181. https:// doi.org/10.1080/03650340.2019.1605166

Huang, M., Zhu, Y., Li, Z., Huang, B., Luo, N., Liu, Ch., \& Zeng, G. (2016). Compost as a soil amendment to remediate heavy metal-contaminated agricultural soil: Mechanisms, efficacy, problems, and strategies. Water, Air and Soil Pollution, 227-359. https://doi.org/10.1007/s11270-016-3068-8

Illmer, P., Barbato, A., \& Schinner, F. (1995). Solubilization of hardly soluble $\mathrm{AlPO}_{4}$ with P- solubilizing microorganisms. Soil Biology and Biochemistry, 27, 260-270. https:// doi.org/10.1016/0038-0717(94)00205-f

Kanwal, U., Ali, S., Shakoor, M.B., Farid, M., Hussain, S., \& Yasmeen, T., et al. (2014). EDTA ameliorates phytoextraction of lead and plant growth by reducing morphological and biochemical injuries in Brassica napus L. under lead stress. Environmental Science and Pollution Research, 21, 98999910. https://doi.org/10.1007/s11356-014-3001-x

Klute, A. (1986). Methods of Soil Analysis, part I, $2^{\text {nd }}$ ed. Madison, Wisconsin, USA. https://doi.org/10.2136/ sssabookser5.1.2ed

Lee, Ch., Park, S., Hwang, H., Kim, M., Jung, H., \& Luyima, D., et al. (2019). Effects of food waste compost on the shift of microbial community in water saturated and unsaturated soil condition. Applied Biological Chemistry, 62, 1-7. https://doi.org/10.1186/s13765-019-0445-1

Mihoub, A., Daddi Bouhoun, M., Asif, N., \& Saker, M.L. (2016). Low-molecular weight organic acids improve plant availability of phosphorus in different textured calcareous soils. Archives of Agronomy and Soil Science, 63, 1023-1034. http://dx.doi.org/10.1080/03650340.2016.1249477

Mihoub, A., Daddi Bouhoun, M., \& Naeem, A. (2018). Shortterm effects of phosphate fertilizer enriched with lowmolecular-weight organic acids on phosphorus release kinetics and its availability under calcareous conditions in arid region. Journal of Scientific Agriculture, 2, 66-70. http://dx.doi.org/10.25081/jsa.2018.v2.884

Mihoub, A., Amin, A.A., Asif, N., \& Daddi Bouhoun, M. (2019) Improvement in phosphorus nutrition of wheat plants grown in a calcareous sandy soil by incorporating chemical phosphorus fertilizer with some selected organic substances. Acta Agriculturae Slovenica, 113(2), 263-272. https://doi.org/10.14720/aas.2019.113.2.7

Negim, O., Eloifi, B., Mench, M., Bes, C., Gaste, H., MotelicaHeino, M., \& Le Coustumer, P. (2010). Effect of basic slag addition on soil properties, growth and leaf mineral composition of beans in a Cu-contaminated soil. Journal of Soil and Sediment Contamination, 19, 174-187. https://doi. org/10.1080/15320380903548508

Ning, D., Liang, Y., Liu, Z., Xiao, J., \& Duan, A. (2016). Impacts of steel-slag-based silicate fertilizer on soil acidity and silicon availability and metals-immobilization in a paddy soil. PLoS ONE, 11, 1-15. https://doi.org/10.1371/journal. pone. 0168163

Page, A.L., Miller, R.H., \& Keeney, D.R. (1982). Methods of Soil Analysis, part II, $2^{\text {nd }}$ ed. Wisconsin, USA.

Płaza, A., Rzążewska, E., \& Gąsiorowska, B. (2021). Effect of Bacillus megaterium var. phosphaticum bacteria and L-Alpha proline amino acid on iron content in soil and Triticum aestivum L. plants in sustainable agriculture system. Agronomy, 11, 511. doi:10.3390/agronomy11030511

Razaq, M., Zhang, P., Shen, H., \& Salahuddin (2017). Influence of nitrogen and phosphorous on the growth and root morphology of Acer mono. PLoS ONE, 12, 1-13. https:// doi.org/10.1371/journal.pone.0171321

Sahin, S., Karaman, M.R., \& Gebologlu, N. (2014). The effect of humic acid application upon the phosphorus uptake of the tomato plant (Lycopersicum esculentum L.). Scientific Research and Essays, 9, 586-590. http://dx.doi.org/10.5897/ SRE2014.581

SAS. (2000). Statistical analysis system, SAS User's Guide: Statistics. SAS Institute Inc., Cary, USA.

Satisha, G., \& Devarajan, L. (2005). Humic substances and their complexation with phosphorus and calcium during composting of press mud and other biodegradables. Communications in Soil Science and Plant Analysis, 36, 805-818. https://doi.org/10.1081/CSS-200049454

Saxena, A.K., Kumar, M., Chakdar, H., Anuroopa, N., \& Bagyaraj, D.J. (2020). Bacillus species in soil as a natural resource for plant health and nutrition. Journal of Applied Microbiology, 128, 1583-1594. doi:10.1111/jam.14506

Soil Survey Staff. (2010). Keys to Soil Taxonomy (11 $1^{\text {th }}$ ed.). Washington, DC: U.S. Department of Agriculture, Natural Resources Conservation Service, U.S. Government Printing Office.

Taiwo, A.M. (2011). Composting as a sustainable waste management technique in developing countries. Journal of Environmental Science and Technology, 4, 93-102. http:// dx.doi.org/10.3923/jest.2011.93.102

Taskin, M.B., Kadioglu, Y.K., Sahin, O., Inal, A., \& Gunes, A. (2019). Effect of acid modified biochar on the growth and essential and non-essential element content of bean, chickpea, soybean, and maize grown in calcareous soil. Communications in Soil Science and Plant Analysis, 50, 1604-1613. https://doi.org/10.1080/00103624.2019.16313 26

Tsakiridis, P.E., Papadimitriou, G.D., Tsivilis, S., \& Koroneos, C. (2008). Utilization of steel slag for Portland cement clinker production. Journal of Hazardous Materials, 152, 805-811. https://doi.org/10.1016/j.jhazmat.2007.07.093

Watanabe, F.C., \& Olsen, S.R. (1965). Test of an ascorbic acid method for determining phosphorus in water and $\mathrm{NaHCO}_{3}$ extracts from soils. Soil Science Society of America Proceedings, 29, 677-678. https://doi.org/10.2136/ sssaj1965.03615995002900060025x

Yildirim, I.Z., \& Prezzi, M. (2011). Chemical, mineralogical, and morphological properties of steel slag. Advances in Civil Engineering, 2011, 1-13. https://doi. org/10.1155/2011/463638 